\title{
PENGARUH PEMBERIAN PUPUK HAYATI CAIR ULTRA GEN DAN PUPUK MAJEMUK NPK MAHKOTA (12-12-17-2) TERHADAP PERTUMBUHAN BIBIT KELAPA SAWIT (Elaeis guineensis Jacq.) DI MAIN NURSERY
}

\author{
Rian Jura Arrazi ${ }^{1}$, Agam Ihsan Hereri ${ }^{1}$, Erida Nurahmi ${ }^{1 *}$ \\ ${ }^{1}$ Program Studi Agroteknologi, Fakultas Pertanian, Universitas Syiah Kuala
}

\begin{abstract}
This study aims to determine the effect of the concentration of ultra gene liquid biofertilizers and crowns compound NPK and to find out whether there is any interaction between the both of it on the growth of oil palm seedlings.This research was carried out at the main nursery land of Nusantara I Plantation Limited Company (PTPN I) Kebun Baru, Langsa City, Aceh Province from June to September 2017. This study used factorial randomized block design with 16 treatments repeated 3 times. This study consisted of two factors, namely the dose of ultra gene liquid biofertilizer 0.100, 200 and $300 \mathrm{ml}$ and the dose of crowns compound NPK fertilizer 0,5,10 and $15 \mathrm{~g}$. The results showed that the dose of Ultra Gen liquid biofertilizer significantly affected the stem diameter, leaf number and leaf area in almost all MSP and significantly affected the leaf area of 6 MSP. The dose of Ultra Gen liquid biofertilizer treatment has a very significant effect on the growth of oil palm seedlings, which is indicated by the parameters of the increase in stem diameter, number of leaves and leaf area, and only a significant effect on leaf area 6 weeks after observation. The dose of $200 \mathrm{ml}$ of the Ultra Gen factor shows better growth than other doses. There is a real interaction on seedling growth as indicated by the parameters of the number of seedlings. The highest number of seed leaves was shown by the treatment of 100 $\mathrm{ml} /$ polybag ultra gen with $\mathrm{NPK} 5 \mathrm{~g} /$ polybag $\left(U_{1} N_{l}\right)$, and $200 \mathrm{ml} /$ polybag with no NPK fertilization $\left(U_{2} N_{0}\right)$, although not significantly different from the $U_{0} N_{0}$ and $U_{3} N_{3}$ treatment combinations, but significantly different with the combination of other treatments.
\end{abstract}

Keywords: crowns NPK, oil palm seeds, ultra gene liquid biofertilizers

\section{PENDAHULUAN}

Kelapa Sawit (Elaeis guineensis Jacq.) merupakan salah satu komoditi dari subsektor perkebunan yang memberi pengaruh penting terhadap perekonomian Indonesia. Produknya tidak hanya untuk memenuhi kebutuhan industri di dalam negeri, tetapi juga memenuhi permintaan pasar ekspor yang kian bertambah sehingga mampu menjaga ketahanan pangan dan ketahanan energi serta memiliki nilai ekonomis tinggi. Oleh sebab itu, di masa akan datang peluang usaha ini sangat menjanjikan. Hal ini dikarenakan keistimewaan produk kelapa sawit itu sendiri maupun permintaan pasar yang semakin meningkat (Maruli, 2012).

Seiring dengan perkembangan luas areal dan produk kelapa sawit cenderung bertambah, selama lima tahun terakhir luas areal perkebunan kelapa sawit di Indonesia sebelum tahun 2016 cenderung menunjukkan pertambahan, naik sekitar $5,38 \%$ hingga $10,96 \%$ per tahun. Pada tahun 2011 perkebunan kelapa sawit indonesia memiliki areal seluas 9,13 juta hektar, bertambah hingga 10,75 juta hektar pada tahun 2015 atau terjadi pertambahan 25,80 persen. Pada tahun 2016 diperkirakan luas areal perkebunan kelapa sawit bertambah sebesar $0,15 \%$ dari tahun 2015 menjadi 
11,12 juta hektar. Sama halnya dengan luas areal kelapa sawit, dari tahun 2011 hingga 2015 perkembangan produksi minyak sawit (CPO) bertambah sekitar $5,38 \%$ hingga $8,42 \%$ per tahun, namun di tahun 2016 diperkirakan menurun 0,15 persen. Pada tahun 2011 produksi minyak sawit (CPO) sebesar 23,99 juta ton, bertambah hingga 31,07 juta ton pada tahun 2015 atau terjadi pertambahan 29,48 persen. Pada tahun 2016 diperkirakan produksi minyak sawit (CPO) akan menurun $0,15 \%$ dari tahun 2015 menjadi 31,02 juta ton (Badan Pusat Statistik, 2016).

Permasalahan umum yang dialami petani sawit swadaya kelapa sawit adalah ketersediaan bibit yang tidak berkualitas, ditunjukkan dengan daya tumbuh yang rendah. Selain itu penggunaan bahan tanam yang kurang optimal, salah satu penyebabnya adalah ketersediaan unsur hara. unsur hara merupakan hal yang sangat penting bagi tanaman tanaman kelapa sawit terutama tanaman muda selama pembibitan, tercukupinya unsur hara di media tanam sangat mempengaruhi pertumbuhan tanaman itu sendiri. Pemupukan adalah salah satu cara yang umum dilakukan dalam pemenuhan unsur hara pada media tanam (Khasanah, 2012).

Penambahan sumber hara didalam tanah dapat dilakukan dengan cara pemupukan yang berupa pemberian pupuk organik maupun pupuk anorganik. sifat fisik, kimia, dan biologi tanah dapat diperbaiki dengan pemberian pupuk organik (Leszczynska dan Malina, 2011; Uwumarongie-Ilori et al., 2012). Kemampuan menahan air dan kapasitas tukar kation tanah dapat ditingkatkan dengan pemberian pupuk organik (Prasetyo dan Suriadikarta, 2006). Apabila tanah tidak mampu memenuhi unsur hara yang dibutuhkan tanaman dengan cukup maka dapat diberikan pupuk anorganik agar mencukupi kebutuhan hara tersebut. Unsur hara $\mathrm{N}$, $\mathrm{P}, \mathrm{K}$, dan $\mathrm{Mg}$ adalah unsur hara esensial yang diperlukan tanaman kelapa sawit dalam jumlah banyak. Pupuk majemuk dapat menyuplai keempat unsur hara tersebut. Pada masa pembibitan dan tanaman belum menghasilkan (TBM) pupuk yang umum digunakan yaitu pupuk majemuk. Pupuk majemuk jenis NPKMg 15:15:6:4 dan NPKMg 12:12:17:2 yang sering digunakan pada masa pembibitan kelapa sawit.( Sukmawan et al., 2015).

Pada penelitian Maulana (2015) menunjukkan bahwa konsentrasi pupuk cair hayati ultra gen tidak berpengaruh nyata terhadap peubah yang diamati kecuali pada jumlah daun umur 45 HST. Konsentrasi 0,8 liter ha ${ }^{-1}$ mendapati hasil yang lebih baik dibandingkan dengan konsentrasi pupuk cair hayati yang lainnya. Konsentrasi $5 \mathrm{ml} / \mathrm{liter}$ air memberikan pengaruh lebih baik dibanding konsentrasi 0,10 , dan 15 $\mathrm{ml} /$ liter air pada pemberian pupuk cair hayati sedangkan pada pupuk NPK pemberian pada dosis $0 ; 4,5$; dan 6,75 g/bibit mendapati pertumbuhan lebih rendah, dosis 2,25 g/bibit memberikan pertumbuhan lebih pada bibit kelapa sawit pada fase pre nursery (Wijaya et al., 2015).

Hasil penelitian Kasno dan Anggria (2016) menunjukkan bahwa pengaruh pupuk NPK tunggal dan majemuk mampu memberikan peningkatan pada pertumbuhan tanaman kelapa sawit. Pengaruh pupuk NPK 11-712 dengan pupuk NPK 15-15-15 sama lebih baik daripada pemberian pupuk NPK tunggal. Dosis terbaik pupuk NPK 11-7-12 pada bibit kelapa sawit adalah 5$6 \mathrm{~g} /$ pohon. Pemberian pupuk NPK $142 \mathrm{~g}$ (100\% dari dosis rekomendasi) meningkatkan panjang pelepah bibit pada umur 9 bulan, berangkasan kering tajuk dan berangkasan kering akar bibit tanaman kelapa sawit di main nursery. Pemberian pupuk organik $36 \mathrm{~g}_{\text {polibag }}{ }^{-1}$ meningkatkan tinggi tanaman, jumlah pelepah, diameter batang, dan $\mathrm{P}$ total bibit kelapa sawit di main nursery. 
Terdapat interaksi antara pupuk NPK dan pupuk organik terhadap bobot kering akar bibit kelapa sawit di main nursery. Interaksi terbaik terdapat pada perlakuan pemberian pupuk NPK 50\% dan organik $36 \mathrm{~g} \mathrm{polibag}^{-1}$ (Adnan, 2015).

\section{METODE PENELITIAN}

Tempat dan Waktu Penelitian

Penelitian ini dilaksanakan di lahan pembibitan main nursery Perseroan Terbatas Perkebunan Nusantara 1 (PTPN 1) Kebun Baru, Kota Langsa, Provinsi Aceh dari bulan Juni sampai September 2017.

Alat dan Bahan Penelitian

Alat yang telah digunakan dalam penelitian ini antara lain adalah fiber drum $1000 \mathrm{~L}$, cangkul, polybag ukuran $50 \mathrm{~cm} \times 40 \mathrm{~cm}$, parang stainless steel, jangka sorong, gelas ukur, meteran/ penggaris dan alat tulis. Bahan yang digunakan yaitu bibit kelapa sawit (Elaeis guneensis Jacq) hasil persilangan Dura dan Pisifera berumur 6 bulan yang berasal dari PPKS marihat sebanyak 96 bibit, konsentrasi pupuk hayati cair Ultra Gen produksi PT Indonusa Panca Raya sebanyak 14,4 Liter, pupuk NPK Majemuk Mahkota (12-12-17-2) PT. Sentana Adidaya Pratama (SADP) sebanyak $720 \mathrm{~g}$.

\section{Rancangan Penelitian}

Penelitian ini menggunakan rancangan acak kelompok (RAK) pola faktorial 4 x 4 dengan 3 ulangan. Ada 2 faktor yang diteliti yaitu konsentrasi pupuk hayati cair ultra gen terdiri atas 4 taraf yaitu $0, \quad 100,200$ dan 300 $\mathrm{ml} /$ polybag dan dosis NPK majemuk mahkota terdiri atas 4 taraf yaitu $0,5,10$ dan $15 \mathrm{~g} /$ polybag. Dengan demikian terdapat 16 kombinasi perlakuan.

\section{Pengamatan}

Parameter yang diamati meliputi: pertambahan tinggi tanaman, pertambahan diameter batang, pertambahan jumlah daun dan pertambahan luas daun. Pengamatan parameter pertumbuhan tersebut dilakukan 2 minggu sekali, setelah aplikasi pupuk.

\section{HASIL DAN PEMBAHASAN}

Pengaruh pupuk hayati cair Ultra gen terhadap pertumbuhan bibit kelapa sawit

Hasil uji $\mathrm{F}$ pada analisis ragam menunjukkan bahwa perlakuan dosis pupuk hayati cair Ultra gen berpengaruh sangat nyata terhadap diameter batang 2 , 4, 6, 8, 10, 12 MSP, Jumlah daun 4, 6, 8, 10,12 , Luas daun $8,10,12$ MSP dan berpengaruh nyata terhadap luas daun 6 MSP. Tetapi berpengaruh tidak nyata terhadap Tinggi tanaman $0,2,4,6,8,10$, 12 MSP, Jumlah daun 2 MSP, Luas daun 2 dan 4 MSP. Rata-rata pertumbuhan bibit kelapa sawit akibat perlakuan konsentrasi pupuk hayati cair ultra gen (Tabel 2).

Pertambahan diameter batang pada 2 MSP hingga 10 MSP dosis terbaik dijumpai pada dosis $100 \mathrm{ml}$ yang berbeda tidak nyata dengan $200 \mathrm{ml}$ dan $300 \mathrm{ml}$, namun berbeda nyata dengan dosis $0 \mathrm{ml}$. peningkatan dosis $100 \mathrm{ml}, 200 \mathrm{ml}$ dan 300 $\mathrm{ml}$ memberikan peningkatan yang positif pada diameter batang . bila dilihat pada 12 MSP penambahan diameter batang terbaik pada dosis $200 \mathrm{ml}$ yg berbeda tidak nyata dengan dosis $300 \mathrm{ml}$, namun berbeda nyata dengan dosis $0 \mathrm{ml}$ dan 100 $\mathrm{ml}$.

Pupuk hayati cair mampu memperbaiki struktur tanah, kemudian juga berperan penting dalam proses perombakan bahan organik serta kandungan unsur hara dari pupuk hayati cair N, P, K, dan C organik diserap secara efektif. Sesuai dengan penelitian Rikamonika (2012) yang berpendapat bahwa pupuk hayati cair berfungsi memberi unsur hara pada tanaman dan tanah, serta mampu meningkatkan pertumbuhan tanaman dikarenakan mengandung unsur hara esensial yang lengkap. Unsur hara $\mathrm{P}$ dan $\mathrm{K}$ berperan 
penting dalam pertambahan diameter batang. Leiwakabessy (1998) menambahkan dalam meningkatkan diameter batang tanaman bahwa tidak terlepas dari peran unsur $\mathrm{P}$ dan $\mathrm{K}$, khususnya dalam peranannya sebagai jaringan yang menghubungkan antara akar dan daun.

Tabel 1. Rata-rata pertambahan parameter pertumbuhan bibit kelapa sawit akibat perlakuan dosis pupuk hayati cair ultra gen

\begin{tabular}{|c|c|c|c|c|c|c|}
\hline \multirow{2}{*}{\multicolumn{2}{|c|}{ Parameter yang diamati }} & \multicolumn{4}{|c|}{ Dosis Ultra Gen (ml/polybag) } & \multirow{2}{*}{$\mathrm{BNJ}_{0.05}$} \\
\hline & & 0 & 100 & 200 & 300 & \\
\hline \multirow{6}{*}{$\begin{array}{l}\text { Pertambahan tinggi } \\
\text { tanaman }(\mathrm{cm})\end{array}$} & $2 \mathrm{MSP}$ & 8.58 & 8.08 & 8.38 & 8.58 & $\operatorname{tn}$ \\
\hline & $4 \mathrm{MSP}$ & 16.99 & 17.72 & 16.60 & 16.50 & tn \\
\hline & $6 \mathrm{MSP}$ & 25.41 & 26.48 & 27.00 & 27.15 & tn \\
\hline & $8 \mathrm{MSP}$ & 42.35 & 44.37 & 42.86 & 43.76 & $\operatorname{tn}$ \\
\hline & 10 MSP & 51.86 & 54.09 & 54.89 & 54.28 & $\operatorname{tn}$ \\
\hline & 12 MSP & 62.96 & 65.58 & 65.77 & 66.00 & $\operatorname{tn}$ \\
\hline \multirow{6}{*}{$\begin{array}{l}\text { Pertambahan diameter } \\
\text { Batang }(\mathrm{cm})\end{array}$} & 2 MSP & $0.35 \mathrm{a}$ & $0.56 \mathrm{ab}$ & $0.72 \mathrm{~b}$ & $0.65 \mathrm{~b}$ & 0.23 \\
\hline & $4 \mathrm{MSP}$ & $0.79 \mathrm{a}$ & $1.25 \mathrm{~b}$ & $1.4 \mathrm{~b}$ & $1.37 \mathrm{~b}$ & 0.42 \\
\hline & $6 \mathrm{MSP}$ & $1.23 \mathrm{a}$ & $2.13 \mathrm{~b}$ & $2.34 \mathrm{~b}$ & $2.33 \mathrm{~b}$ & 0.46 \\
\hline & $8 \mathrm{MSP}$ & $1.65 \mathrm{a}$ & $2.97 \mathrm{~b}$ & $3.2 \mathrm{~b}$ & $3.22 \mathrm{~b}$ & 0.53 \\
\hline & 10 MSP & $2.16 \mathrm{a}$ & $3.78 \mathrm{~b}$ & $3.89 \mathrm{~b}$ & $4.28 \mathrm{~b}$ & 0.99 \\
\hline & 12 MSP & $2.59 \mathrm{a}$ & $4.62 \mathrm{~b}$ & $5.18 \mathrm{bc}$ & $5.34 \mathrm{c}$ & 0.57 \\
\hline \multirow{6}{*}{$\begin{array}{l}\text { Pertambahan jumlah } \\
\text { Daun (pelepah) }\end{array}$} & $2 \mathrm{MSP}$ & 0.54 & 0.67 & 0.83 & 0.75 & tn \\
\hline & $4 \mathrm{MSP}$ & $1.13 \mathrm{a}$ & $1.46 \mathrm{ab}$ & $1.75 \mathrm{~b}$ & $1.92 \mathrm{~b}$ & 0.53 \\
\hline & $6 \mathrm{MSP}$ & $1.83 \mathrm{a}$ & $2.33 \mathrm{ab}$ & $2.88 \mathrm{bc}$ & $3.17 \mathrm{c}$ & 0.65 \\
\hline & $8 \mathrm{MSP}$ & $2.50 \mathrm{a}$ & $3.38 \mathrm{~b}$ & $4.04 \mathrm{bc}$ & $4.50 \mathrm{c}$ & 0.69 \\
\hline & $10 \mathrm{MSP}$ & $3.33 \mathrm{a}$ & $4.25 \mathrm{~b}$ & $5.04 \mathrm{c}$ & $5.63 \mathrm{c}$ & 0.69 \\
\hline & 12 MSP & $4.17 \mathrm{a}$ & $5.33 \mathrm{~b}$ & $6.21 \mathrm{c}$ & $6.75 \mathrm{c}$ & 0.65 \\
\hline \multirow{6}{*}{$\begin{array}{l}\text { Pertambahan luas Daun } \\
\left(\mathrm{cm}^{2}\right)\end{array}$} & $2 \mathrm{MSP}$ & 0.78 & 0.89 & 1.00 & 0.93 & tn \\
\hline & $4 \mathrm{MSP}$ & 1.55 & 1.91 & 2.10 & 2.45 & tn \\
\hline & $6 \mathrm{MSP}$ & $1.87 \mathrm{a}$ & $2.20 \mathrm{a}$ & $2.62 \mathrm{ab}$ & $3.00 \mathrm{~b}$ & 0.88 \\
\hline & $8 \mathrm{MSP}$ & $2.22 \mathrm{a}$ & $2.74 \mathrm{ab}$ & $3.19 \mathrm{~b}$ & $3.59 \mathrm{~b}$ & 0.96 \\
\hline & 10 MSP & $2.39 \mathrm{a}$ & $2.96 \mathrm{ab}$ & $3.66 \mathrm{bc}$ & $4.08 \mathrm{c}$ & 1.11 \\
\hline & 12 MSP & $2.80 \mathrm{a}$ & $3.56 \mathrm{ab}$ & $4.87 \mathrm{c}$ & $5.30 \mathrm{c}$ & 1.22 \\
\hline
\end{tabular}

Keterangan : Angka yang diikuti oleh huruf yang sama pada baris yang sama berbeda tidak nyata pada taraf $5 \%\left(\mathrm{Uji}_{\mathrm{BNJ}} \mathrm{B}, 05\right) ; \mathrm{MSP}=$ minggu setelah pengamatan

Jumlah daun pada 4 MSP terbaik pada $100 \mathrm{ml}$ yang berbeda tidak nyata dengan 200 dan $300 \mathrm{ml}$, namun berbeda nyata dengan $0 \mathrm{ml}$. Pada 6 MSP hingga 12 MSP dosis $200 \mathrm{ml}$ dan $300 \mathrm{ml}$ memberikan peningkatan terbaik dibandingkan dosis lainnya. Dapat dilihat pada Tabel 1 hasil penelitian yang telah dilakukan, selain jumlah daun meningkat seiring umur tanaman, juga lebih banyak dibandingkan pertumbuhan standar bibit kelapa sawit di main nursery, karena sifat morfologi tanaman kelapa sawit menurut Harder dan Fairhurst (2003), rata-rata pertumbuhan pelepah kelapa sawit antara 1-3 buah per bulan.

Pemberian pupuk hayati cair Ultra Gen dapat mencukupi kebutuhan unsur hara bagi tanaman, terutama unsur $\mathrm{N}$ dan $\mathrm{P}$ dalam pembentukan daun dengan cepat, proses pembelahan dan pembesaran sel yang menyebabkan daun mudah lebih cepat mencapai bentuk sempurna peran bantu dari unsur $\mathrm{N}$ dan $\mathrm{P}$ 
pada media. Hal ini sesuai dengan pendapat Lakitan (2000) yang menyatakan bahwa pembentukan daun dalam hal bentuk dan jumlah pengaruh dari tercukupinya unsur $\mathrm{N}$ dan $\mathrm{P}$, Lebih lanjut Sutedjo dan Kartasapoetra (1991) menyatakan bahwa unsur $\mathrm{N}$ berfungsi untuk meningkatkan pertumbuhan daun. Pertambahan daun kelapa sawit dipengaruhi tingkat kesuburan tanah dan keadaan musim (Pahan, 2008).

Luas daun pada 6 MSP terluas pada dosis $200 \mathrm{ml}$ yang berbeda tidak nyata dengan dosis lainnya. dosis $200 \mathrm{ml}$ berbeda tidak nyata dengan $300 \mathrm{ml}$, namun berbeda nyata dengan dosis $0 \mathrm{ml}$ dan $100 \mathrm{ml}$ pada $12 \mathrm{MSP}$. Hal tersebut diduga karena keberhasilan pupuk ultra gen menghasilkan unsur hara yang memiliki karakteristik slow release dan dalam bentuk partikel sangat kecil (nano) bagi tanaman dengan mengedepankan teknologi.

Ukuran hara yang sangat halus akan memudahkan dalam penyerapan dan pencernaan oleh tanaman baik perakaran, stomata dan jaringan meristem. Karena ukuran yang kecil dan mudah diserap dan dicerna, maka jumlah penggunaan pupuk dapat dihemat tanpa mengurangi hasil produksi panen (Ultragen, 2016). Juga diperkuat Pendapat Saleh et al. (2008) menambahkan bahwa di bidang pertanian khususnya bagi para agronomis peran mikroba sangatlah penting di dalam kemampuan menyuplai tersedianya nutrisi. Kegiatan memperkenalkan mikroba dalam bentuk agensia hayati menjadi alternatif untuk mengurangi penggunaan pupuk kimia dan mewujudkan sistem pertanian berkelanjutan.

\section{Pengaruh pupuk majemuk NPK Mahkota terhadap pertumbuhan bibit kelapa sawit}

Hasil uji $F$ pada analisis ragam menunjukkan bahwa perlakuan dosis pupuk NPK majemuk Mahkota berpengaruh tidak nyata terhadap semua pertambahan parameter pengamatan, namun tampak adanya peningkatan yang lebih baik pada dosis 15 gr dibandingkan dosis lainnya (Tabel 2.).

Adanya pengaruh tidak nyata pemberian pupuk majemuk NPK mahkota terhadap pertumbuhan bibit diduga akibat pemberian dosis yang masih terlalu rendah sehingga mengakibatkan pengaruh yang tidak maksimal terhadap tanaman karena unsur hara masih dalam jumlah sedikit atau belum tersedia dalam meningkatkan sumber hara bagi tanah yang berdampak terhadap daya tumbuh tanaman. Sejalan dengan pendapat Hassink (1994) bahwa hal yang paling utama dalam mengendalikan jumlah $\mathrm{C}$ dan $\mathrm{N}$ untuk dimineralisasi yang mempengaruhi kesuburan tanah faktor kunci dalam mengendalikan jumlah $\mathrm{C}$ dan $\mathrm{N}$ untuk dimineralisasi yang mempengaruhi kesuburan tanah adalah jumlah, aktivitas, dan kualitas biomassa mikroorganisme. Perlunya kesesuaian dosis yang tepat dalam pemberian pupuk, sangat baik pengaruh pemberian pupuk yang tepat namun jika pemberian berlebihan akan berpengaruh tidak baik terhadap pertumbuhan pada bibit (Lubis, 2008). 
Tabel 2. Rata-rata Pertambahan parameter pertumbuhan bibit kelapa sawit akibat perlakuan dosis pupuk NPK majemuk Mahkota

\begin{tabular}{|c|c|c|c|c|c|c|}
\hline \multirow{2}{*}{\multicolumn{2}{|c|}{ Parameter yang diamati }} & \multicolumn{4}{|c|}{ Dosis NPK (g/polybag) } & \multirow{2}{*}{$\mathrm{BNJ}_{0.05}$} \\
\hline & & 0 & 5 & 10 & 15 & \\
\hline \multirow{6}{*}{$\begin{array}{l}\text { Pertambahan } \\
\text { tinggi tanaman } \\
\quad(\mathrm{cm})\end{array}$} & 2 MSP & 7.29 & 8.79 & 8.17 & 9.38 & \multirow{6}{*}{ tn } \\
\hline & 4 MSP & 16.54 & 16.92 & 16.43 & 17.91 & \\
\hline & $6 \mathrm{MSP}$ & 25.12 & 27.63 & 25.93 & 27.37 & \\
\hline & $8 \mathrm{MSP}$ & 42.32 & 44.19 & 41.20 & 45.63 & \\
\hline & $10 \mathrm{MSP}$ & 51.38 & 55.26 & 50.74 & 57.74 & \\
\hline & $12 \mathrm{MSP}$ & 62.69 & 67.06 & 61.02 & 69.54 & \\
\hline \multirow{6}{*}{$\begin{array}{c}\text { Pertambahan } \\
\text { diameter Batang } \\
(\mathrm{cm})\end{array}$} & 2 MSP & 0.52 & 0.56 & 0.63 & 0.57 & \multirow{6}{*}{ tn } \\
\hline & $4 \mathrm{MSP}$ & 1.15 & 1.19 & 1.25 & 1.24 & \\
\hline & $6 \mathrm{MSP}$ & 1.96 & 1.99 & 2.03 & 2.05 & \\
\hline & $8 \mathrm{MSP}$ & 2.63 & 2.75 & 2.74 & 2.93 & \\
\hline & $10 \mathrm{MSP}$ & 3.10 & 3.55 & 3.62 & 3.84 & \\
\hline & $12 \mathrm{MSP}$ & 4.25 & 4.33 & 4.49 & 4.65 & \\
\hline \multirow{6}{*}{$\begin{array}{l}\text { Pertambahan } \\
\text { jumlah Daun } \\
\text { (pelepah) }\end{array}$} & 2 MSP & 0.79 & 0.75 & 0.58 & 0.67 & \multirow{6}{*}{ tn } \\
\hline & $4 \mathrm{MSP}$ & 1.58 & 1.63 & 1.42 & 1.63 & \\
\hline & $6 \mathrm{MSP}$ & 2.5 & 2.6 & 2.5 & 2.6 & \\
\hline & $8 \mathrm{MSP}$ & 3.58 & 3.50 & 3.54 & 3.79 & \\
\hline & $10 \mathrm{MSP}$ & 4.58 & 4.42 & 4.54 & 4.71 & \\
\hline & $12 \mathrm{MSP}$ & 5.54 & 5.46 & 5.67 & 5.79 & \\
\hline \multirow{6}{*}{$\begin{array}{c}\text { Pertambahan luas } \\
\text { Daun } \\
\left(\mathrm{cm}^{2}\right)\end{array}$} & 2 MSP & 1.03 & 0.89 & 0.82 & 0.86 & \multirow{6}{*}{ tn } \\
\hline & $4 \mathrm{MSP}$ & 1.83 & 1.71 & 2.41 & 2.06 & \\
\hline & $6 \mathrm{MSP}$ & 2.23 & 2.03 & 2.88 & 2.56 & \\
\hline & 8 MSP & 2.74 & 2.66 & 3.11 & 3.23 & \\
\hline & $10 \mathrm{MSP}$ & 3.01 & 2.86 & 3.53 & 3.68 & \\
\hline & $12 \mathrm{MSP}$ & 3.67 & 3.74 & 4.49 & 4.63 & \\
\hline
\end{tabular}

Keterangan: Angka yang diikuti oleh huruf yang sama pada baris yang sama berbeda tidak nyata pada taraf $5 \%\left(\mathrm{Uji} \mathrm{BNJ}_{0,05}\right) ; \mathrm{MSP}=$ minggu setelah pengamatan

Interaksi pupuk hayati cair Ultra Gen dan pupuk NPK majemuk Mahkota terhadap pertumbuhan bibit kelapa sawit

Hasil Uji $F$ pada analisis ragam (Tabel 3 ) menunjukkan bahwa terdapat interaksi yang nyata antara perlakuan pupuk hayati cair Ultra Gen dengan perlakuan pupuk NPK majemuk Mahkota terhadap jumlah daun 2 MSP, namun terdapat interaksi yang tidak nyata terhadap parameter yang diamati lainnya. Rata-rata interaksi pupuk hayati cair Ultra Gen dengan perlakuan pupuk NPK majemuk Mahkota terhadap jumlah daun 2 MSP dapat dilihat pada Tabel 3.
Hasil penelitian menunjukkan bahwa kombinasi perlakuan antara pupuk hayati cair Ultra Gen dan pupuk NPK majemuk Mahkota hanya berpengaruh nyata pada pertumbuhan jumlah daun 2 MSP. Perlakuan lebih baik dijumpai pada dosis pupuk hayati cair ultra gen $100 \mathrm{ml}$ dan dosis NPK majemuk mahkota $5 \mathrm{~g}$ $\left(\mathrm{U}_{1} \mathrm{~N}_{1}\right)$ serta dosis pupuk hayati cair ultra gen $200 \mathrm{ml}$ dan dosis NPK majemuk mahkota $0 \mathrm{~g}\left(\mathrm{U}_{2} \mathrm{~N}_{0}\right)$ dengan nilai 1,17 yang berbeda nyata dengan $\left(\mathrm{U}_{0} \mathrm{~N}_{3}\right)$, $\left(\mathrm{U}_{1} \mathrm{~N}_{0}\right)$ dengan nilai 0,17 dan $\left(\mathrm{U}_{0} \mathrm{~N}_{2}\right)$ dengan nilai 0,33 , namun berbeda tidak nyata dengan perlakuan lainnya. 
Tabel 3. Interaksi konsentrasi pupuk hayati cair Ultra Gen dan dosis pupuk NPK majemuk Mahkota terhadap jumlah daun bibit kelapa sawit pada pengamatan 2 MSP

\begin{tabular}{|c|c|c|c|c|c|}
\hline \multirow{2}{*}{$\begin{array}{l}\text { Dosis Ultra gen } \\
\text { (ml/polybag) }\end{array}$} & \multicolumn{4}{|c|}{ Dosis Pupuk NPK (g/polybag) } & \multirow{2}{*}{$\mathrm{BNJ}_{0.05}$} \\
\hline & $0\left(\mathrm{~N}_{0}\right)$ & $5\left(\mathrm{~N}_{1}\right)$ & $10\left(\mathrm{~N}_{2}\right)$ & $15\left(\mathrm{~N}_{3}\right)$ & \\
\hline $0\left(\mathrm{U}_{0}\right)$ & $1.00 \mathrm{bc}$ & $0.67 \mathrm{abc}$ & $0.33 \mathrm{ab}$ & $0.17 \mathrm{a}$ & \multirow{4}{*}{0.8} \\
\hline $100\left(\mathrm{U}_{1}\right)$ & $0.17 \mathrm{a}$ & $1.17 \mathrm{c}$ & $0.50 \mathrm{abc}$ & $0.83 \mathrm{abc}$ & \\
\hline $200\left(\mathrm{U}_{2}\right)$ & $1.17 \mathrm{c}$ & $0.67 \mathrm{abc}$ & $0.83 \mathrm{abc}$ & $0.67 \mathrm{abc}$ & \\
\hline $300\left(\mathrm{U}_{3}\right)$ & $0.83 a b c$ & $0.50 \mathrm{abc}$ & $0.67 \mathrm{abc}$ & $1.00 \mathrm{bc}$ & \\
\hline
\end{tabular}

Keterangan: Angka yang diikuti oleh huruf yang sama, berbeda tidak nyata pada taraf $5 \%\left(\mathrm{Uji}_{\mathrm{BNJ}} \mathrm{BN}_{0,05}\right.$ ); $\mathrm{MSP}=$ minggu setelah pengamatan 
Pengaruh kombinasi perlakuan yang nyata antara pupuk hayati cair Ultra Gen dan pupuk NPK majemuk Mahkota terhadap jumlah daun diduga disebabkan Azosprillium sp, Azotobacter sp, Pseudomonas sp dan bakteri Selulotik yang terkandung dalam pupuk hayati yang dapat mendekomposisikan lebih lanjut bahan organik yang terdapat pada pupuk hayati cair Ultra Gen dan melepaskan unsur-unsur yang berada di dalam pupuk anorganik seperti $\mathrm{K}, \mathrm{N}, \mathrm{Ca}$, $\mathrm{Mg}$ menjadi bahan tersedia yang dapat diserap oleh bibit tanaman kelapa sawit.

Perlakuan pupuk hayati cair dan pupuk majemuk NPK meningkatkan pertumbuhan jumlah daun kelapa sawit secara nyata. Quansah (2010) menyatakan bahwa campuran pemberian pupuk organik dengan anorganik akan meningkatkan pertumbuhan tanaman dikarenakan bahan organik dapat membenahi kondisi tanah sehingga unsur hara lebih tersedia bagi tanaman. Herviyanti et al. (2012) menyatakan bahwa KTK tanah dapat di tingkatkan oleh tanah-tanah dengan kandungan bahan organik tinggi dan mampu mengikat unsur hara, sehingga efektivitas pemupukan anorganik juga meningkat. Aplikasi pupuk organik juga dapat diserap secara perlahan dan digunakan tanaman untuk jangka panjang (Ermadani dan Muzar, 2011).

\section{KESIMPULAN}

Perlakuan konsentrasi pupuk hayati cair Ultra Gen berpengaruh sangat nyata terhadap pertumbuhan bibit tanaman kelapa sawit, yang ditunjukkan dengan parameter pertambahan diameter batang, jumlah daun dan luas daun bibit, dan hanya berpengaruh nyata terhadap luas daun 6 minggu setelah pengamatan. Dosis $200 \mathrm{ml}$ factor Ultra Gen menunjukkan pertumbuhan yang lebih baik dibanding dosis lainnya. Perlakuan dosis pupuk majemuk NPK Mahkota tidak berpengaruh nyata terhadap semua parameter pengamatan yang diamati, meskipun secara visual dosis $15 \mathrm{~g}$, menunjukkan pertumbuhan yang lebih baik. Terdapat interaksi yang nyata terhadap pertumbuhan bibit yang ditunjukkan oleh parameter jumlah daun bibit. Jumlah daun bibit terbanyak ditunjukkan oleh perlakuan pemberian ultragen $100 \mathrm{ml} /$ polybag pada dosis NPK $5 \mathrm{~g} /$ polybag $\left(\mathrm{U}_{1} \mathrm{~N}_{1}\right)$, dan $200 \mathrm{ml} /$ polybag pada tanpa pemupukan NPK $\left(\mathrm{U}_{2} \mathrm{~N}_{0}\right)$, meskipun tidak berbeda nyata dengan kombinasi perlakuan $\mathrm{U}_{0} \mathrm{~N}_{0}$ dan $\mathrm{U}_{3} \mathrm{~N}_{3}$, tetapi berbeda nyata dengan kombinasi lainnya.

\section{DAFTAR PUSTAKA}

Adnan IS. 2015. Pengaruh Pupuk NPK dan Pupuk Organik terhadap Pertumbuhan Bibit Kelapa Sawit (Elaeis guineensis Jacq.) di Main Nursery. Jurusan Budidaya Tanaman Perkebunan. Politeknik Negeri Lampung. Bandar Lampung.

Badan Pusat Statistik. 2016. Statistik Kelapa Sawit Indonesia. Jakarta. Indonesia. Balai Informasi Pertanian.

Hardter R and Fairhust T. 2003. Oil Palm Management for Large and Suistainable Yields. Potash \& Phospate Institute. Canada.

Hassink J. 1994. Effects of soil texture on the size of microbial biomass and on the amount of $\mathrm{C}$ and $\mathrm{N}$ mineralized perunit of microbial biomass in Dutch grassland soils. Soil Biol. Biochem. 26:1573-1581.

Herviyanti A, Fachri, Riza S, Darmawan, Gusnidar, Amrizal S. 2012. Pengaruh pemberian bahan humat dan pupuk P pada Ultisol. J. Solum 19:15-24.

Kasno dan Anggria. 2016. Peningkatan Pertumbuhan Kelapa Sawit di Pembibitan dengan Pemupukan NPK. Balai Penelitian Tanah Jalan. Bogor. 
Lakitan B. 2000. Dasar-Dasar Fisiologi Tumbuhan. Raja Grafindo Persada. Jakarta.

Leiwakabessy FM. 1998. Kesuburan Tanah. IPB Press. Bogor.

Leszczynska DJ dan Malina N. 2011. Effect of organic matter from various sources on yield and quality of plant on soils contaminated with heavy metals. Ecol. Chem. Eng. S. 18:501-507.

Lingga. 1995. Petunjuk Pengunaan Pupuk. Penebar Swadaya. Jakarta.

Lubis AR. 1992. Kelapa Sawit di Indonesia. Pusat Penelitian Bandar Kuala Marihat Pematang Siantar. Sumatera Utara.

Lubis AU. 2008. Kelapa Sawit (Elaeis guineensis Jacq.) Di Indonesia. Edisi 2. PPKS RISPA. Medan

Maulana Z. 2015. Pengaruh Pemberian Pupuk Cair Hayati Terhadap Pertumbuhan dan Hasil Dua Varietas Tanaman Jangung (Zea mays L.) Fakultas Pertanian. Universitas Syiah Kuala. Banda Aceh.

Pahan I. 2008. Kelapa Sawit. Penebar Swadaya. Jakarta.

Pitojo S. 1995. Penggunaan Urea Tablet. Penebar Swadaya. Jakarta.

Prasetyo BH dan Suriadikarta DA. 2006. Karakteristik, potensi, dan teknologi pengelolaan tanah Ultisol untuk pengembangan pertanian lahan kering Indonesia. J. Litbang Pertanian. 25:39-47

Quansah, G. W. 2010. Improving soil productivity through biochar amendments to soils. Africa $J$. Environ. Sci. and Tech. 3:34-41.

Rasyidin. 1983. Budidaya Tanaman Perkebunan Umum (Kultur Kelapa Sawit). Fakultas Pertanian Universitas Sumatera Utara, Medan.

Rikamonika. 2012. Respon tanaman kelapa sawit terhadap pupuk fosfat alam berkualitas tinggi untuk mendorong peningkatan produksi tanaman perkebunan. [Skripsi] Jurusan Agroteknologi. Fakultas Pertanian. Universitas Sumatera Utara. Medan.

Saleh N. Rahmianna AA, Pardono, Samanhudi, Anam C. dan Yulianto. 2008. Prosiding Seminar Nasional Pengembangan Kacang-kacangan dan Umbi-Umbian, Surakarta, 7 Agustus 2008. Fakultas Pertanian/Pascasarjana Agronomi Universitas Sebelas Maret Surakarta, Balai Penelitian Tanaman Kacang-kacangan dan Umbi-umbian, dan Balai Pengkajian Teknologi Pertanian Jawa Tengah. HIm. 76-81 .

Saraswati R. 2012. Teknologi Pupuk Hayati untuk Efisiensi Pemupukan dan Berkelanjutan Sistem Produksi Pertanian. Badan Litbang Pertanian. Bogor.

Sukmawan Y, Sudradjat dan Sugiyanta. 2015. Peranan pupuk organik dan NPK majemuk terhadap pertumbuhan kelapa sawit TBM 1 di Lahan Marginal. Skripsi. Jurusan Budidaya Tanaman Perkebunan. Politeknik Negeri Lampung

Sutedjo, M. M. dan Kartasapoetra. 1991. Pupuk dan Pemupukan. Rineka Cipta. Jakarta. Poeloengan, Z., M. L. Fadli, Winarna, S. Rahutomo, dan E.S. Sutarta. 2003. Permasalahan Pemupukan pada Kelapa Sawit. dalam W. Darmosarkoro, E. G. Sutarta, dan Winarna (Eds.). Lahan dan Pemupukan Kelapa Sawit. PPKS. Medan.

Uwumarongie-Ilori EG, Sulaiman-Ilobu $\mathrm{BB}$, Ederion $\mathrm{O}$, Imogie A, Imoisi BO, Garuba N, Ugbah M. 2012. Vegetatife growth performance of oil palm (Elaeis guineensis) seedlings in response to inorganic and organic fertilizer. Greener J. Agric. Sci. 2:26-30

Wijaya IGA, Ginting J, dan Haryati. 2015. Respons Pertumbuhan Bibit 
Kelapa Sawit (Elaeis guineensis Jacq.) di Pre Nursery terhadap Pemberian Limbah Cair Pabrik Kelapa Sawit dan Pupuk NPKMg (15:15:6:4). Program Studi Agroekoteknologi. Fakultas Pertanian, Universitas Sumatera Utara. 